\title{
Scoring the Census Priority Table for Age Heaping and Shifting: A Study of 2006 Nigeria Population Census Result
}

\author{
Okafor Samuel 0* \\ Department Of Sociology/Anthropology, University Of Nigeria, Nsukka
}

Submission: January 14, 2018; Published: January 29, 2018

"Corresponding author: Okafor Samuel 0, Department of sociology/anthropology, University of Nigeria, Nsukka, Nigeria, Tel: +2348034853595; Email: samuelokey200@gmail.com

\begin{abstract}
Over the years, Nigeria had been struggling with census problems, which mainly have to do with appropriate data collection and management. This situation has drastically affected the quality of population data made available to the public and by implication, discourage sensitive research ventures which mainly rely on the census data in the country. Similarly, this has affected the structure and direction of development policies and projects in Nigeria which only sound plausible but cannot be realizable due to discrepancies between the population realities, and the assumptions on the paper (census results). This study focused on the 2006 population census result using the population priority table to statistically assess the quality of age reporting with the aid of whipple index and the sex ratio of the aged (85 years and above).

The Whipple index assumption, is that all things being equal, the index will have the value of 100 if there is no age preference and avoidance in the ages ending in ' 0 ' \& ' 5 ' digits. However, the extent of deviation from 100 either on the negative or positive side, determines the level of age shifting or age heaping. Meanwhile, according to the findings, only few states had some level of accuracy which revealed in essence the lapses and high level of irregularities in the 2006 census exercise. Never the less, the assessment of the age ratio among the population (85 years and above) show that apart from Edo state, Lagos state and Ogun, every other state including the F C T, show evidence of manipulated data on the side of the census officials, and inconsistency in age reporting on the side of the populace. The study recommends proper enlightenment of the public on the age issues as it concerns population census, and proper training of enumerators to prevent confusion on the issue of respondents understanding about age.
\end{abstract}

Keywords: Age accuracy; Population census; Sex ratio; Social Research; Whipple index

\section{Introduction}

The ignorance of the essence of population census is among the most atrocities committed among the government agents who had been entrusted with the provision of accurate data on the population issues in Nigeria. This lackadaisical attitude does not only affect the surface nature of the census results which are more or less, political argument however, the most painful aspect of this is the misleading information to the researchers across all disciplines who rely heavily on census data in conducting some level of studies requiring the data on the entire citizens of the nation. Of paramount concern is the accuracy of age data in the census which can be needed for many reasons such as accurate policy on birth control, economic policy, the direction of population increase or decrease and the impact of socio economic and political events, such as wars, epidemic, e.tc.

Though the population manipulators and their staunch allies in the government have relied on the confusion created by the colonial masters to argue consistency in the region which could be higher and the ones that have sparse population, there are over whelming evidences that censuses such as the 2006 population census was a mere allocation of figures than field exercise.

Meanwhile for an empirical evaluation, the present study is focused to adopt certain statistical techniques such as Whipple index and other age accuracy index, in investigating the accuracy of 2006 population results. Having presented the interest of this study, other steps involved include: statement of the problem, literature review, methodology, presentation of findings, discussion of the findings and conclusion/recommendations.

\section{Statement of the Problem}

The importance of census and census data to every economy is very salient as the phenomenon is among the factors which are responsible for the advancement of the industrialized 
nations, world over. The elementary principle for planning and development of any nation is availability of a reliable and detailed demographic data of the nation. This can be actualized through census data and the willingness of those concerned in providing such information [1,2]. According to Mimiko [3], population census data are critically important for equitable political and economic representation of a citizen on various levels of government. According to Akinbode [4], the infrastructural development may not be realizable in the absence of the knowledge and information about the population of a nation as can be provided by population census. The knowledge of population in terms of its size and composition has a far reaching implication for change, development and the quality of life in the society [5].

Census among the developed nations has aided researches in different capacities and areas of socio economic and political activities in the society as empirical evidences have shown [6-9].

Though there are a lot of benefits accrued to census data in the planning and development of the society, Nigeria as one of the African developing nations that had never conducted a census which is credible enough to yield a reliable data for developmental planning. For instance, every census held in Nigeria before and after independence has ended in national controversy, strong allegations of population falsification and manipulation [1]. Reviewing the chronicles of census planning and administration in Nigeria since Nigerian independence, Okafor (2006) discovered that the 2006 census exercise produced one out of the numerous provocative results which has no direct connection to reality. In an attempt to explain the reasons behind the inconsistency and unreliability of the census results in Nigeria, many scholars have offered some levels of explanations using empirical data (both primary and secondary data). Adiele [10], after painstakingly analyzing the trends in the post independence censuses, using official documents, maintained that falsification of census result for group and private gains was the normal practice by the NPC and their collaborators elsewhere.

More so, such situation is attributed to the failure of National Population Commission to Institutional corruption [11]. Mimiko [3], analyzed the time frame and the census manuals in the post independent censuses in Nigeria and found that the condition in which census are conducted in Nigeria end up leading to the publishing of biased census results. Similarly, Onwuka [12], associating the Nigerian population from 1980-2003, and the rate of population growth using regression analysis, discovered that the census results released so far and the reality in Nigerian population phenomenon are far from each other. He attributed this to the adhoc arrangement in the preparation for census. According to the United Nations [13], most African countries (Nigeria included), have never produced census result which can be reliable for economic and health planning, for reasons ranging from ethnic sentiments to political instability.
In support to the United Nations concern about the effect of ethnicity on the population censuses in African Nations such as Nigeria, Muogbo, Fagbemi \& Subair [14], Matthews [15,16] using historical indices and the pattern of colonial administration in Nigeria, discovered that the vestiges of colonialists' segregation and disproportional arrangement were responsible for the unreliability of census results in Nigeria. These according to them, were responsible for the cancellations of 1963 and 1973 census results. Though it appeared to the public that after the ceremonial hand over in 1960, colonial masters left; the realities on the ground have shown that the colonial masters only infused their stooges in the system after they were sure of having psychologically structured them to maintain their socioeconomic and political pattern which they have laid as foundation $[17,18]$.

In a more historic perspective, Ittman [19] reviewed what he termed "the causes and consequences of census taking in Africa by the European colonialists". According to him, due to the dust Malthus raised in Europe and the innate fear by the empire controllers that the expansion of African population will hinder their dominance, the colonialists embarked on ill prepared census when they lack staffs to do so. This resulted in the culture of epileptic census exercise and results. Consequently, the adhoc approach, which the colonialists gave to census exercises in most African nations, was responsible for lack of adequate and comprehensive demographic information in some African nations especially with regard to census and vital registration data $[20,21]$.

In the light of Ittman's observation, there are a lot of confusions which the colonialist's divide and rule administration left in the system. For instance, while the colonialist agents in the South were battling to secure the means of evaluating the potential tax payers via population census, which ignored the entire population and focused on the taxable adults, the few of their agents who were dancing to the tune of the northern Muslim enclave were busy supplying the empire administrators with population figures manufactured in the office. Okolo [22], Okafor, Adeleke \& Oparac [23], studied the pattern of results and census conducts from 1866-1991 and 1961-2006 respectively, they discovered some factors which had rendered census taking in Nigeria irrelevant.

In their conclusion after cross examination of census results in Nigeria since independence, Odewumi [24] and Onyekakeya [25], maintained that culture, lack of information and ethnic sentiment, holds a strong ground in what people interpret census exercise to be. This of course brings about the question about age reporting and its implication to the quality of census data in Nigeria. The quality of age reporting in Nigeria is one of the factors which seriously affect the quality of the entire results per se. Age reporting is one of the essential part of census data which inform other higher degree research ventures [26]. In view of the arguments and counter argument about the 2006 census result and its predecessors, using Whipple index and 
other age accuracy index, the present study is poised to answer the following questions through the 2006 population priority table;

a. What is the extent of accuracy in the age reporting in the 2006 Nigerian population census?

b. Towards which direction (Region) can we find the errors in the age reporting?

c. What is the general over view of the 2006 Nigerian population census in terms of quality of data and age reporting?

d. Does the age ratio among the aged in the 2006 census correspond to the Nigerian life table/life expectancy in terms of males and females and the global standard?

\section{Literature Review}

\section{Age reporting in census data}

Over the century, the quality of census result is most times measured through the quality of age reporting in the data. This is because, the level of accuracy in age reporting determines to larger extent, the validity of the data in predicting the population of the group in question, in the nearest future [27]. As a result of its importance in determining the quality of census data, different techniques had been developed to evaluate the extent of accuracy in the population data especially, the single age population data, among these techniques are the Whipple index [and the recent modifications], the Myers Blended method, the United Nations joint age and sex scores Bachi index, etc [28-30].

The major focus of all these techniques is to test for age heaping and shifting, and the extent of accuracy via the sex structure of the census data. According to Bwalya, Phiri \& Mwansa [31], tests of the age preference are not only important because of the major role it plays in describing the population but also because of its importance in making population projections and planning for resource distribution by government agencies and other stakeholders easy.

One of the major factors in the problem of underdevelopment in most African countries, can be traced to the lack of proper age reporting in the census data which in itself is connected to other issues such as lack of adequate awareness during census exercise, memory loss among the citizens and even deliberate manipulation of census figures during and after census exercises. Data on age in developing countries are subject to errors, particularly in circumstances where literacy levels are not high. A common error in age reporting is the tendency of rounding the agesto the nearest figure ending in ' 0 ' or ' 5 ' or to a lesser extent, to the nearest even number [32].

\section{Census Data and Research}

Census across the globe especially among the developed nations has aided researches in different capacities and areas of socio economic and political activities in the society. Zaruth,
Jasilionis \& Jdanor [6] using the census data, were able to unveil the changes in educational differentials in old age mortality in Finland and Sweden between 1971-1975 and 1996-2000. The census-linked mortality datasets were retrieved from statistics Finland and statistics Sweden for the analysis of trend of changes in life expectancy among the males and females using education and gender as independent variables. According to them, the educational gap in life expectancy at age 65 and the total amount of mortality inequality by education, as reflected by average inter-group difference, increased in both countries. For males in Finland, there was gain in life expectancy between 1.9 to3.2 years whereas among females it was between 2.0 to 2.3.In Sweden; it was 1.4-2.7 for males and 2.1-3.2 years for females. Saika, Singh, Jasilionis \& Ram [7] working through the census data and demographic health survey, explained the rural urban differences in infant mortality in India and also, the socio economic and cultural variables behind the gap. Such factors according to them included access to maternal care, educational attainment, and cultural orientation about health care and personal hygiene, etc. The puzzle about the high frequent divorce among the Lithuanians after the intrusion of capitalism was explained with the aid of population census data by Maslauskaite, Jasilionine, Jasilinis, Starkumiene \& Shkolmikov [8].

The study utilized the 2001 Lithuania population and housing census and the first divorce records from the Lithuania population register covering the census date (April 2001) and the end of the follow-up (31 December 2003).Forty one thousand first legal divorce and 3.18 million person-years of married years of exposure were analyzed, with the observation of education, employment/unemployment, geographical location, gender and disability-related inactivity. The study found the evidence of individual socioeconomic resources having substantial differentiating effects on first divorce risks in Lithuania. The direction and size of these effects vary notably by sex and place of residence.

Having access to the census data, Vallin, Andreev, Mesle [9], studied cause of death, patterns and trends in Russia. Dividing the entire region into four clusters (Chemoziom, Russian South, Seberia and European North), using the 1970,1979,1989 and 1994 censuses. They were able to trace the changes in mortality rate within the Russian provinces. This was in reaction to the 1985 and 1992-93 anti alcohol campaign by the government as a result of deteriorating life expectancy. Poveda (2007) working on the extent and nature of migration in South of Veracruz, Mexico was able to explain the socioeconomic and political determinants of migration both in and out migration, using the census and DHS data from Mexican authority. Using the census data from Wales and England, Jdanov, Andreev, Jasilionis \& Shkolnikov [33] estimated the changes in mortality and population in England and Wales over the two world wars.

The researchers combining the England and Wales populations that were involved in military recruitment compared 
the death according to the military record and the trend of mortality among the civilian population between 1914-1918 and 1940-1945. With observation of age and probability of dying, the study finds mortality rate higher among the age 18-24 more than any other age group. Also, the probability of dying was found to be $15 \%$ higher during the two war periods more than any other period. In essence, these show the extent to which census data can be used to actualize other valuable research interests. Having a census data which have a near accuracy age data can perfectly guide policies as well as other researches which can inform other policies. Policies per se, are the life wire of every economy and by implication requires bias free information.

\section{Methodology}

The study utilized the Federal Republic of Nigeria 2006 Population and Housing Census Priority Table Volume IV Population Distribution by Age \& Sex (State \& Local Government Area). This included the distribution of the population, both in single year and five years intervals. Due to the statistical equation (Whipple Index) adopted, the study utilized only the single year age data to investigate and analyze the extent of age shifting/ heaping, and its direction in terms of states and regions.

Meanwhile, the study adopted the Whipple index...as;

$\mathrm{WI}=(\Sigma(\mathrm{P} 30+\mathrm{P} 40+\ldots+\mathrm{P} 50+\mathrm{P} 60) / 1 / 5(\Sigma(\mathrm{P} 23+\mathrm{P} 24+\ldots+\mathrm{P} 61$ $+\mathrm{P} 62)) \times 100(1)$,

$\mathrm{WI}=(\Sigma(\mathrm{P} 25+\mathrm{P} 35+\ldots+\mathrm{P} 45+\mathrm{P} 55) / 1 / 5(\Sigma(\mathrm{P} 23+\mathrm{P} 24+\ldots+\mathrm{P} 61$ $+\mathrm{P} 62)) \times 100(2)$.

To test the age heaping around the digits ' 0 '\& ' 5 '. According to the interpretation of Whipple index, while 100-125 show some degrees of accuracy in age reporting, above 125- 500 show the extent of age heaping and by implication, how bad the age data is in the census report. Nevertheless, figures below 100 show the extent of age shifting from the digits ' 0 ' \& ' 5 ' [34]. Where extreme deviation [age shifting] was suspected, the age data were separated into ' 0 ' and ' 5 ' to ascertain the reliability if the result. Finally, the study tested the reliability of the 2006 Nigerian census result via the age ratio at old age ( 85 and above) (Table 1).

Table 1: South East Digit Preference Index Based On The 2006 Census Data.

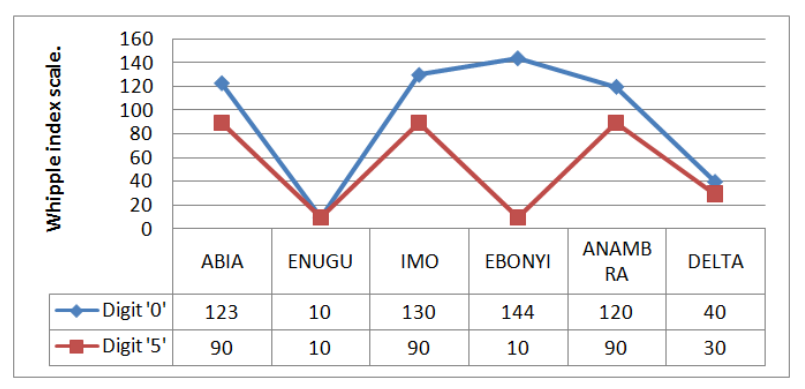

10-20-30-40-50-60-70-80-90-100-110-120-130-140-150-160-170-180-190-200-....

Keys: While green indicate the absolute accuracy, light green \& blue indicate partial accuracy and red indicate high level of deviation.

\section{Presentation of Findings}

The table above revealed the extent of accuracy and deviation in age reporting according to the 2006 population census in Nigeria within the South East geopolitical zone. According to the result, there are evidences of age heaping as well as age shifting. While 100 on the scale (Whipple index) indicate accuracy in age reporting, above the score of 100 indicate age heaping while below the score of 100 indicate age shifting. Thus, the result from Abia State show that there was age heaping in the figures ending in " 0 " while there was the same time, age shifting from the figures ending in " 5 ". The same applies to all the states in the South East geopolitical zone (Table 2).

Table 2: North east digit preference index based on the 2006 census data.

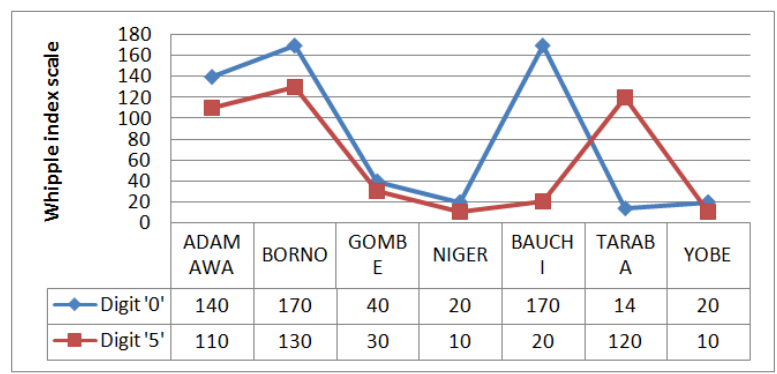

10-20-30-40-50-60-70-80-90-100-110-120-130-140-150-160-170-180-190-200-..

Keys: While green indicate the absolute accuracy, light green \& blue indicate partial accuracy and red indicate high level of deviation.

According to the result, it was only in Adamawa state that near accuracy (110) was recorded in the ages ending in " 5 " while results from other states indicate some levels of inaccuracy showing, the extent of age heaping and age shifting. Furthermore, the result revealed the extent to which people were aware and willing to give out accurate information about their age as well as the level of manipulation of the census data by the enumerators in the areas involved (Table 3).

Table 3: North west digit preference index based on the 2006 census data.

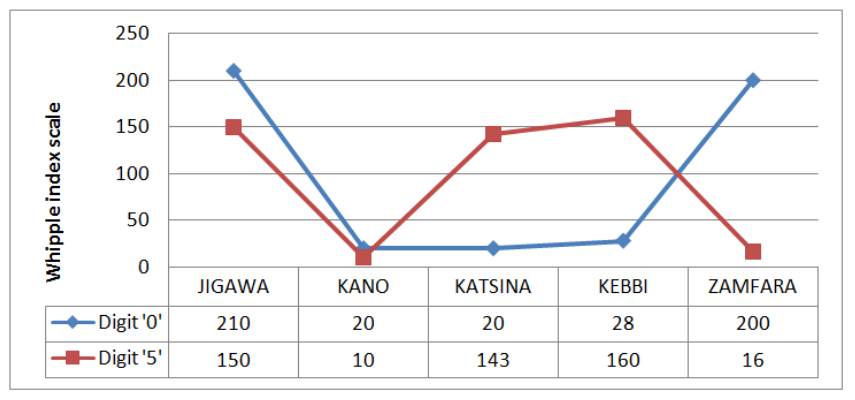

10-20-30-40-50-60-70-80-90-100-110-120-130-140-150-160-170-180-190-200-

Keys: While green indicate the absolute accuracy, light green \& blue indicate partial accuracy and red indicate high level of deviation.

According to the result in the Table 3, there was extreme deviation from the accuracy point which is 100 . This is an indication of lack of cooperation between the census enumerators and the public in these states. More so, the data show the 
evidence of data manipulation and indiscriminate assignment of figures to different states involved (Table 4).

Table 4: North Central Digit Preference Index Based On The 2006 Census Data.

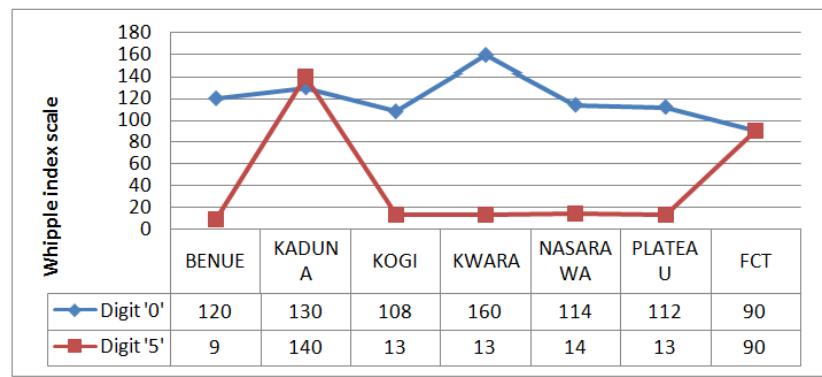

10-20-30-40-50-60-70-80-90-100-110-120-130-140-150-160-170-180-190-200-

Keys: While green indicate the absolute accuracy, light green \& blue indicate partial accuracy and red indicate high level of deviation.

According to the Table 4, it was only in Federal Capital Territory that the 2006 census exercise recorded near accuracy in the ages ending in " 5 " while other areas in the region show extreme deviation from the accuracy point, indicating age heaping and shifting. In the ages ending in " 0 ", there were evidences of some degree of accuracy except, in Kaduna state Benue state and Kwara state where there high level of deviation from the accuracy point (Table 5).

Table 5: South West Digit Preference Index Based On The 2006 Census Data.

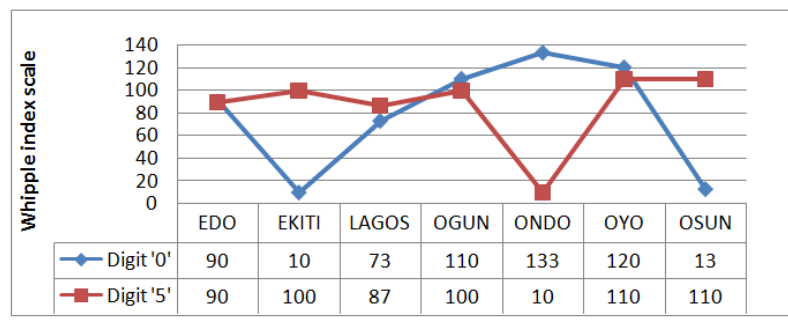

10-20-30-40-50-60-70-80-90-100-110-120-130-140-150-160-170-180-190-200-.

Keys: While green indicate the absolute accuracy, light green \& blue indicate partial accuracy and red indicate high level of deviation.

Table 6: South South Digit Preference Index Based On The 2006 Census Data.

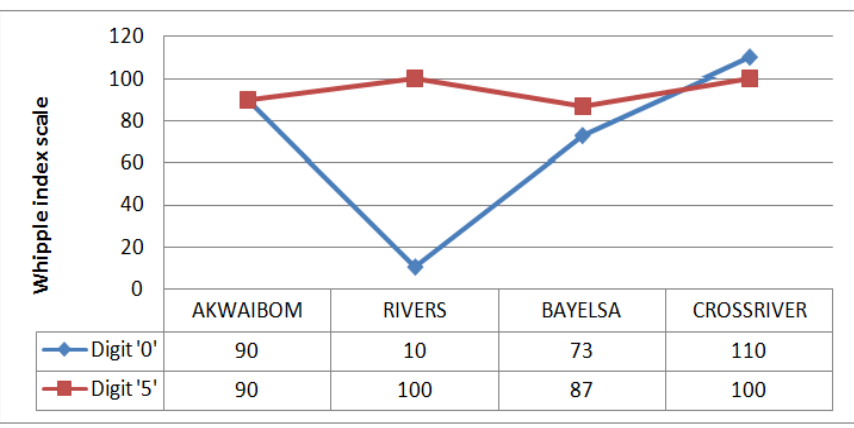

$10-20-30-40-50-60-70-80-90-100-110-120-130-140-150-160-170-180-190-200-\ldots . .$.

Keys: While green indicate the absolute accuracy, light green \& blue indicate partial accuracy and red indicate high level of deviation.
According to the result here, it were only in Lagos state and Ondo state that show extreme deviation from accuracy point in the ages ending in " 5 " while other states within this region show different level of accuracy in the age ending in " 5 ". Meanwhile, in the ages ending in "0" only Ogun state and Edo state show some level of accuracy while other show some degrees of deviation indicating age heaping and age shifting (Table 6).

Table 7: The sex ratios in the 2006 census result.

\begin{tabular}{|c|c|c|c|}
\hline States & $\begin{array}{c}\text { Males by } \\
\text { Percentage (\%) }\end{array}$ & $\begin{array}{c}\text { Females by } \\
\text { Percentage (\%) }\end{array}$ & $\begin{array}{l}\text { Ratio of Males } \\
\text { to Females: }\end{array}$ \\
\hline Abia & 54.2 & 45.8 & 118.1 \\
\hline Adamawa & 55.6 & 44.4 & 125.4 \\
\hline Akwaibom & 63.7 & 36.3 & 175.3 \\
\hline Anambra & 60 & 40 & 143.7 \\
\hline Bauchi & 59.1 & 40.9 & 144.6 \\
\hline Benue & 58.3 & 41.7 & 139.9 \\
\hline Bayelsa & 63.3 & 36.7 & 172.7 \\
\hline Borno & 59.4 & 40.6 & 146.3 \\
\hline Crossriver & 59.7 & 40.3 & 148.3 \\
\hline Delta & 51.8 & 48.2 & 107.5 \\
\hline Edo & 49.6 & 50.4 & 98.4 \\
\hline Ekiti & 57.8 & 42.2 & 136.9 \\
\hline Enugu & 55.9 & 44.1 & 126.5 \\
\hline Ebonyi & 59 & 41 & 144.1 \\
\hline Gombe & 59.8 & 40.2 & 148.9 \\
\hline Imo & 59.7 & 40.3 & 148.2 \\
\hline Jigawa & 60.9 & 39.1 & 156 \\
\hline Kaduna & 57.7 & 42.3 & 136.5 \\
\hline Kano & 56.8 & 43.2 & 131.3 \\
\hline Katsina & 60.1 & 39.9 & 150.5 \\
\hline Kebbi & 58.4 & 41.6 & 140.2 \\
\hline Kogi & 61.1 & 38.9 & 157 \\
\hline Kwara & 54.2 & 45.8 & 118.4 \\
\hline Lagos & 43.7 & 56.3 & 77.5 \\
\hline Nasarawa & 62.2 & 37.8 & 164.4 \\
\hline Niger & 62.4 & 37.6 & 165.7 \\
\hline Ogun & 43.4 & 56.6 & 76.5 \\
\hline Ondo & 52.1 & 47.9 & 108.7 \\
\hline Оyо & 52.4 & 47.6 & 110.1 \\
\hline Plateau & 54.3 & 45.7 & 119 \\
\hline Rivers & 59.5 & 40.5 & 146.6 \\
\hline Sokoto & 55.1 & 44.9 & 122.9 \\
\hline Taraba & 61.3 & 38.7 & 158.1 \\
\hline Osun & 57.9 & 42.1 & 137.5 \\
\hline Yobe & 58.7 & 41.3 & 142 \\
\hline Zamfara & 58.4 & 41.6 & 140.3 \\
\hline $\mathrm{F} \mathrm{C} \mathrm{T}$ & 55 & 45 & 122.2 \\
\hline
\end{tabular}


Keys: Green lines indicate evidence of proper age data in the census data while, red indicate the evidence of improper data or manipulated data in the areas concerned.

According to the result, there was near accuracy in the ages ending in "0" in Cross River and Akwalbom while, Rivers and Bayelsa show high level of deviation from the accuracy point. In the ages ending in " 5 ", there was accurate age reporting in both Cross River and Rivers while there were some level of deviation in Akwalbom and Bayelsa (Table 7).

According to the result, only Edo state, Lagos and Ogun state show evidence of proper age data in the 2006 census exercise and by implication, Indicate that the census conduct in the area recorded some level of progress. Every other state, with red line, indicated lack of cooperation by the public and an evidence of manipulation of data. This is predicated on the fact that the existing standard in population structure according to United Nations [13] has shown that from the base of population pyramid, there are more males compared to females while at the top which show the older members of the population, there more females. Consequently, the Nigerian life expectancy shows that the total population life expectancy is 52.62 for the total population; while that of the male is 51.63 , the female is 53.66 years [World Fact Book, 2016]. This by implication shows the extent of disparity between the 2006 census data and the realities on ground.

\section{Discussion of the Findings}

The present study was focused on re-analyzing of the 2006 population census priority table which contained the detailed information on age distribution in the population. According to Whipple index which had been adopted here in analyzing the age accuracy in the census data, among the digits selected to be tested [as " 0 " $\&$ " 5 " had been selected here], the index is expected to be 100 if the age data in the census is accurate. The level of accuracy is expanded to some points to ignore certain degrees of human errors which are inescapable; the expansion of the level of accuracy is in the following order: 101-125 on the positive side and at least 95-90 on the negative side. While the continuous movement on the positive side indicates the extent of age heaping, the continuous movement towards the negative side indicate age shifting. However, both the positive and negative sides all indicate the extent of degrading value of the census data.

The above results on the analysis of the Nigerian 2006 population census result indicate that there were huge evidences of errors beyond what may be seen as politically motivated arguments which followed the result of the census when it was published. There are disparities in the various regions according to the present analysis, which indicated that in different parts of the country, the 2006 census exercise met with some level of challenges both on the side of the general public and the census officials.

The result from the South-East show that for the ages ending in "5", only Abia, Imo and Anambra with the score of 90 came close to 100 which are the accuracy score under Whipple index statistical equation. Others such as Enugu, Ebonyi and Delta were very far from the accuracy score, showing how bad the census data from the area were. Consequently, for the ages ending in "0", only Abia with 123 and Anambra with 120 were closed to accuracy. The overall data from the area showed high level of age shifting and age heaping and moreover, some level of misconduct on the side of the census officials.

For the North-East geopolitical zone, only Adamawa with 110 and Taraba with 120 show evidence of accurate age data for ages ending in " 5 ". Other states within the region showed evidence of gross deviation from accurate age data. For the ages ending in " 0 ", none of the states in the region show evidence of accurate age data and by implication, a sign of gross misconduct on the side of the census officials. According to the result for the North-West geopolitical zone, there were worst age data in the census result showing gross misconduct on the side of the census officials and outright allocation of figures to the different states in the zone. In the North-Central, there were a reasonable evidence of proper census conduct in the area for instance; five states such as Benue [120], Kogi [108], Nasarawa [114], Plateau [112] and F C T [90] show some level of accuracy in the ages ending in " 0 ". On the other hand, except the F C T with 90, all the states in the region show evidence of gross deviation from accurate age data for the ages ending in " 5 ".

Again, this show some level of inconsistency which can be as a result of misconception of age and unwillingness to give out accurate information on age among the public. In the South-West geopolitical zone there are over whelming evidence of properly conducted census exercise as the age data from the area indicated minor deviation from accuracy with some states showing exert accuracy in the ages ending in " 0 " $\&$ " 5 ". For the South-South geopolitical region, there is also solid evidence of some level of accuracy in the age data both in the ages ending in " 0 " \& " 5 ".

In the overall data, the result showed that the south west witnessed census exercise which was neutral and properly conducted with the cooperation of the general public; this is also evidence in the south-south region while the North-Central region showed some level of consistency which is the evidence the census was conducted at all. In the South-East region, the data is pointing to some level of lack of cooperation from the public and also some level of manipulation of the data. In the North-East, there is little evidence of the enumerators visiting the field but without proper coordination. Also from the NorthEast is the evidence of manipulation of census figure. Finally, in the North-West, there was no census conducted in the area as the analysis showed evidences of arbitrary allocation of figures to different states there.

\section{Conclusion}

The importance of accurate census data cannot be over emphasized as it is the bedrock of development planning and research on socio-economic and political issues. This is evidence 
in economically developed nations where consistency in census data encourages proper development planning. In the case of many developing nations where census issues are being taken for granted, socio economic and political planning always meet with failures because of lack of proper information about the existing population. The way each nation approaches the issue of her population, largely determine the extent of accuracy in the planning of her economic and political arrangements hence, poor knowledge and observation of population data result to poor economic and political planning. Though age accuracy related problems are blamed on the public for lack of cooperation with the census enumerators, the enumerators and census organizing officials are not exonerated from the problems as some evidences point to the fact that most times, these caliber of people in census administration are also culprits in the mater.

For example, lack of proper enlightenment to the public on what the enumerators mean by age can result to misconception of age by the larger part of the people being counted. Consequently the outright allocation of figures to different groups based on assumption instead of real data can surface as error on age data when subjected to statistical analysis. These by implication show that the general public who may be accused for the errors in age data during census exercise only contribute an insignificant part of it.

\section{Recommendations}

Based on the Foregoing, this study is recommending to the government officials who are saddled with the responsibility of conducting census, to observe the following for proper conduct of census exercise:

I. The general public should be properly enlightened on the issue of age at least before the census and during the census while on house to house enumeration.

II. The enumerators should be properly trained to understand the yardstick for age recording so as to be able to elicit proper information from the general public on one on one interview.

III. Instead of spend the huge amount usually paid to the ghost enumerators; the officials should consider a precensus panel survey to have a glimpse of the type of situation they are likely to face during the main exercise.

IV. Spirit of patriotism should be encouraged among the enumerators and the general public before and during the census period.

\section{References}

1. Eniayejuni AT, Agoyi M (2011) A Biometrics Approach to Population Census and National Identification in Nigeria: A Prerequisite for Planning and Development. Asian Transactions on Basic \& Applied Sciences 1(5): 60-67.

2. Ottong JG (2010) The population situation in Cross River State of Nigeria and its implication for socioeconomic development:
Observations from the 1991 and 2006 censuses. Journal of Emerging Trends in Educational Research and policy studies 1(1): 36-42.

3. Mimiko F (2006) Census in Nigeria: The Politics and the Imperative of Depolarization. African and Asian Studies 5(1): 1-22.

4. Akingbade A (2004) Geospatial Data Infrastructure for Nigeria: Foundation for Further development. GIM International Magazine 9(18): 12-15.

5. Ezeah P, Iyanda C, Nwangwu C (2013) Challenges of National Population Census and Sustainable Development in Nigera: A Theoretical Exposition. Journal of Humanities and Social Science 18 (1): 50-56.

6. Zaruth V, Jasilionis D, Jdanov DA (2012) Changes in educational differentials in old-age mortality in Finland and Sweden between 1971-1975 and 1996-2000. Journal of demographic research 26(19): 489-510.

7. Saikia N, Singh A, Jasilionis D, Ram F (2013) Explaining the rural-urban gap in infant mortality in India. Journal of Demographic research 29(18): 473-506.

8. Maslauskaite A, Jasilioniene A, Jasilionis A, Stankuniene V, Shkolnikov VM (2015) Socio-economic determinants of divorce in Lithuania: Evidence from register-based census-linked data. Journal of Demographic research 33(30): 871-908.

9. Vallin J, Andreev E, Meslé F, Shkolnikov V (2005) Geographical diversity of cause-of-death patterns and trends in Russia. Demographic research 12(13): 323-380.

10. Adiele BJ (2009) Falsification of population census data in a heterogeneous Nigerian state: The fourth republic. African Journal of Political Science and International Relations 3(8); 311-319.

11. Okafor SO (2016) Misconception of Population Census and Vital Registration in Nigeria: A Factor in Socio Economic and Political Stagnation. International Journal of Novel Research in Humanity and Social Sciences 3(4): 63-71.

12. Onwukan EC (2006) Another Look at the Impact of Nigeria's Growing Population on the Country's Development. African Population Studies 21(1): 1-18.

13. United Nations (2008) Principles and Recommendations for Population and Housing Censuses, UN Publications, New York, USA.

14. Muogbo O, Fagbemi S, Subair G (2007) Kano has largest population in Nigeria. Centre for Planning Studies Lagos State, Lagos, Nigeria.

15. Mathews MP (2002) Nigeria: Current issues and historical background. Hauppauge, Nova Publishers, New York, USA.

16. Suberu RT (2001) Federalism and ethnic conflict in Nigeria. Washington DC, US Institute of Peace Press, USA.

17. Falola T (2008) A history of Nigeria, Cambridge, Cambridge University Press, UK.

18. Stock RF (2004) Africa South of the Sahara: a geographical interpretation. Guilford Press, New York, USA.

19. Karl Ittmann (2010) Where Nature Dominates Man: Demographic Ideas and Policy in British Colonial Africa 1890-1970. Ohio: University Press, USA.

20. Karl Ittmann (2013) A Problem of Great Importance: Population, Race and Power in the British Empire, 1918-1973. University of California Press, Berkeley, USA.

21. Karl Ittmann (2014) Population Policy, Demographic Theory and Historical Demography: Rethinking African Population Narratives. ASA meeting 2014.

22. Okolo A (1999) The Nigerian Census: Problem and Prospects. The American Statistician 53(4): 321-325. 
23. Okafor R, Adeleke I, Oparac A (2007) An appraisal of the conduct and provisional results of the Nigerian population and housing census of 2006. Section on Statistical Education pp. 2199-2205.

24. Odewumi S (2000) Problems of Census in Nigeria, In: Odumosu T, Atere W, Adewunmi F (Eds), Social Problems and Planning Studies in Nigeria, Centre for Planning Studies Lagos State University, Lagos, Nigeria.

25. Onyekakeyah L (2007) Paradox of Population distribution in Nigeria in the Guardian. Lagos, Nigeria.

26. Economic and Social Commission for Western Asia (ESCWA) (2013). A study of Age Reporting in Some Arab Censuses of Population.

27. Pal JK, Mukhopadhyay BK, Gupta SK (2015) Myers Blended Method: An Alternative Approach. Journal of Scientific Research and Reports 3(18): 2459-2465.

28. Palamuleni ME (1995) Age misreporting in Malawian censuses and sample surveys: An application of the United Nations Joint Age and Sex Score. Southern African Journal of Demography 5(1): 11-17.

29. Pardeshi GS (2010) Age heaping and accuracy of age data collected during a community survey in the Yavatmal district, Maharashtra. Indian Journal Community Medicine 35(3): 391-395.

30. Myers RJ (1940) Errors and bias in the reporting of ages in census data Transaction of the Actuarial Society of America 41(2): 395-415.

31. Bwalya BB, Phiri M, Mwansa C (2015) Digit Preference and its Implications on Population Projections in Zambia: Evidence from the Census Data. International Journal of Current Advanced Research 4(5) 92-97.

32. Yazdanparast A, Amin MP, Abadi A (2012) Digit preference in Iranian age data. Italian Journal of Public Health. 9(1): 64-70.

33. Jdanov D, Andreev E, Jasilionis D, Shkolnikov V (2005) Estimates of mortality and population changes in England and Wales over the two World Wars. Journal of demographic research 13(16): 389-414.

34. Shryock H, Siegel J (1976) The Methods and Materials of Demography. Academic Press, San Diego, USA.

35. Adim F (2007) Delay in release gave room for manipulation In the Guardian. Lagos, Nigeria.

36. Akerele T (2007) Matters arising In the Guardian. Lagos, Nigeria.

37. Alberto Del Rey Poveda (2007) Determinants and consequences of internal and international migration: The case of rural populations in the south of Veracruz, Mexico. Demographic research 16(10): 287-314.

38. Alonso W, Starr P (1982) The political economy of Nigeria. Statistics. Social science research council items 36(3): 29-35.

39. Aluko SA (1965) How Many Nigerians? An Analysis of Nigeria's Census Problems, 1901-1963. Journal of Modern African Studies 3(3): 371392

40. Ayodele T (2007) Disquiet as population result affirms old pattern In the Guardian. Lagos, Nigeria.

41. Bates N, Mulry M (2011) Using a Geographic Segmentation to Understand, Predict, and Plan for Census and Survey Mail Nonresponse. Journal of Official Statistics 27(4): 601-618.

42. Bates N, Woblewski MJ, Pascale J (2012) Public Attitudes Toward the Use of Administrative Records in the U.S. Census: Does Question Frame Matter?. Center for Survey Measurement Census Bureau, US.

43. Bates N, Conrey F, Zuwallack R, Billia D, Harris V, et al. (2009) Messaging to America: Census Barriers, Attitudes and Motivators Survey Results. 2010 Census Integrated Communication Research Memorandum Series: No. 10. Census Bureau, USA.

44. Beaud Jean Pierre (2012) Des usages politiques de la statistique. Policy Options 79-82.
45. Beaujot R (2012) Why do we still need a census?: Revised version of presentation at Panel on "Why do we still need a census" organized by the International Migration Centre, the Canadian Association of Geographers and the Canadian Population Society, Waterloo, Canada.

46. Bertino AJ (2008) Forensic Science: Fundamentals and investigations, Stanford Conneticut: Cengage Learning, USA.

47. Burton J, Sala E, Knies G (2011) Correlates of obtaining informed consent to data linkage: Respondent, interview and interviewer characteristics. A paper presented at the Fourth Conference of the European Survey Research Association (ESRA), Lausanne, Europe.

48. Carr Saunders AM (1936) World Population: Past Growth And Present Trends. Oxford: Clarendon Press, USA.

49. Cassedy J (1969) Demography in early America: Beginning of statistical mind, 1600-1800. Cambridge Havard university press, UK.

50. Central Intelligence Agency World Fact Book (2016). Nigerian people 2016.

51. Dare LO (1975) Nigerian Military Governments and the quest for legitimacy January 1966-July 1975. The Nigerian Journal of Economic and Social Studies 17(2): 95-118.

52. Dare LO (1974) The Dilemma of military disengagement: the Nigerian case. The Nigerian Journal of Economic and Social Studies 16(2): 297309.

53. Dillon Lisa (2010) The value of the long form Canadian census for long term national and international research. Canadian Public Policy 36(3): 389-393.

54. Ekanem II (1972) The 1963 Nigerian Census: A Critical Appraisal. Publishing Corporation, Benin, West Africa.

55. Fay RE, Bates N, Moore J (1991) Lower mail response in the 1990 Census: A preliminary interpretation. Proceedings of the Annual Research Conference 3-32, Washington DC: Census Bureau, US.

56. Fellegi Ivan (2011) Statistics, public confidence and lessons from the story of the 2011 Canadian Census. Symons Lecture, Canada.

57. Fosu GB (2001) Evaluation of population census data through demographic analysis: Symposium on Global Review of 2000 Round of Population and Housing Censuses: Mid Decade Assessment and Future Prospects. Statistics Division Department of Economic and Social Affairs United Nations Secretariat, New York, US.

58. Gates GW (2011) How Uncertainty about Privacy and Confidentiality is Hampering Efforts to More Effectively Use of Administrative Records in Producing U.S. National Statistics. Journal of Privacy and Confidentiality 3(2): 3-40.

59. Green David A, Kevin Milligan (2010) The importance of the long form census to Canada. Canadian Public Policy 36(3): 383-388.

60. Gurr TR (1970) Why Men Rebel. Princeton University Press, New Jersey, USA.

61. Ikeji, CC (2011) Politics of revenue allocation in Nigeria: A reconsideration of some contending issues. Sacha Journal of Policy and Strategic Studies 1(1): 121-136.

62. Inekwe, Murumbai (2014) Hundred Years of Revenue Sharing in Nigeria: The Need for a Rethink. Journal of Good Governance and Sustainable Development in Africa 2(2): 1-8.

63. Jian AK (2008) Hand book of Biometrics. Springer, New York.

64. Ketende S, Calderwood L, McDonald JW (2011) Longitudinal consent patterns and predictors of consent to linkage of survey data in the Millennium Cohort Study. A paper presented at the Fourth Conference of the European Survey Research Association (ESRA), Lausanne, Europe. 
65. Kolapo Y, Faloseyi M (2007) Lagos and the fallacies in national census In Guardian. Lagos, Nigera.

66. Korbmacher J, Schroeder M (2011) Non response when linking survey data with administrative data. A paper presented at the Fourth Conference of the European Survey Research Association (ESRA), Lausanne, Europe.

67. Li SZ (2009) Encyclopedia of Biometrics. Springer, New York (2), USA.

68. Madans J (2011) Use of Administrative Records and the PrivacyConfidentiality Trade-off. Journal of Privacy and Confidentiality 3(2): 53-55.

69. Maines D (1977) Social organization and social structure in symbolic interactionist thought, Annual Review of Sociology (3): 235-259.

70. Makinwa PK (1985) Population Data: The importance of Census, Sample Survey and Vital Registration System. Population Education Monograph 15, Nigerian Educational Research Council, Lagos, Nigeria.

71. Martin E (2007) Changes in Public Opinion during the Census1: Paper presented at the Census Advisory Committee of Professional Associations October 19, 2000.Research Report Series. Census Bureau, USA.

72. Momoh A, Adejumobi S (Eds) (1999) The Nigerian Military and the crisis of Democratic Transition A Study in the Monopoly of power. Lagos: Civil Liberties Organization, Nigera.

73. Musa S (2006) The Census, A foundation for improved Planning and Development in Nigeria. Paper presented at the Distinguished Lecture Series to Mark the 1st Year anniversary of Census" 06 in Enugu, Nigera.

74. Odukomaiya, AM (2002) An Appraisal of the 1991 Census of the Nigerian Population. Project Report, Department of Mathematics, University of Lagos, Nigeria.

75. Ogunbodede EF (2006) Developing Geospatial Information for Poverty Reduction: Lessons and Challenges from Nigeria's 2006 Census. GSDI-9 Conference Proceedings, 6-10 November 2006, Santiago, Chile, South America.

76. Ojo BA (1998) Nigeria's Third Republic: the problems and prospects of political transition to civil rule. Commack, Nova Publishers, New York, USA.

77. Okafor RO (2004) Matters Arising from the 1991 Census of the Nigerian Population; Proceedings of the Conference of the Nigeria Statistical Association, Nigeria.

78. Okafor S (1981) Indirect Rule: The Development of Central Legislation in Nigeria. Nelson Press, Nigeria.

79. Okereka OP (2015) Vital Civic Registration System as a Tool for Development Planning in Nigeria: An Examination of the Major Challenges. Journal of Culture, Society and Development 11: 36-42.

80. Oluleye JJ (1985) Military Leadership in Nigeria 1966-1979. Ibadan, University Press Limited, Nigera.

81. Olusanya PO (1989) Population and Development Planning in Nigeria In: Tamuno T and Atanda JA (Eds) Nigeria since Independence the First 25 years Government and Public Policy. Ibadan, Nigeria.
82. Omotoso F (2010) Nigerian fiscal federalism and revenue allocation formula for sustainable development in Niger Delta. Medwell Journals 5(3): $246-253$.

83. Pascale J (2011) Requesting Consent to Link Survey Data to Administrative Records. A paper presented at the Fourth Conference of the European Survey Research Association (ESRA), Lausanne, Nigera.

84. Pew Research Center (2010) Young People Make Up Large Proportion of Census Hold-Outs.

85. Pew Research Center (2015) Most View Census Positively, But Some Have Doubts.

86. Ritzer G (2011) Classical Sociological Theory, New York: McGraw-Hill, USA

87. Rulof Burger, Ronelle Burger (2004) Emergent Black Affluence and Social Mobility in Post-Apartheid South Africa. Development Policy Research Unit.

88. Rulof B, Dieter v (2009) Determining the Causes of the Rising South African Unemployment Rate. Working Paper Number 158.

89. Salaudeen L (2004) The failed 1991 Census. Lagos, Nigera.

90. Salawu B (2009) Strengthening Vital Registration as Source of Demographic Data For Effective Socio Economic Development In Nigeria. Pakistan Journal of Social sciences 6(4): 200-206.

91. Shagodoyin DK, Oluwayemisi OA (2008) Nigeria Population Dymics and its implication for Development, Medwell Online Journals 3(2).

92. Sharma RK (2004) Demography and population problems. Atlantic Publishers \& Distributors, New Delhi, India.

93. Shryock HS, Siegel JS (1973) The Methods and Materials of Demography, Washington, DC: Department of Commerce, Bureau of the Census, US.

94. Shyrock HS Siegel JS (1976) The methods and Materials of Demography. Condensed edition by Edward G. Stockwell (Eds), Academic Press, New York, USA.

95. Skerry P (2000) Counting on the census? Race, group identity and the evasion of politics. Brookings Institution Press. Massachusetts, US.

96. Suharto S, Volkov 0 (1993) Overview of emerging trends and issues in the 1990 censuses. Annual meeting of population association of America. Ohio, US.

97. Visaria L, Visaria P (1995) India's Population in Transition. Popul Bull 50(3): 1-51.

98. Vladimir M, Shkolnikov, Alexander D Deev, Øystein Kravdal, Tapani Valkonen (2004) Educational differentials in male mortality in Russia and northern Europe. A comparison of an epidemiological cohort from Moscow and St. Petersburg with the male populations of Helsinki and Oslo. Demographic research 10(1): 1-26.

99. Weeks JR (1999) Population: An Introduction to Concepts and Issues tenth edition. Adworth Ltd, London.

100. Woods R (1982) Population Analysis in Geography. New Zealand Journal of Geography 73(1): 1-21. 

(C) (C) $_{\text {BY }}^{\text {This work is licensed under Creative }}$
Your next submission with Juniper Publishers will reach you the below assets

- Quality Editorial service

- Swift Peer Review

- Reprints availability

- E-prints Service

- Manuscript Podcast for convenient understanding

- Global attainment for your research

- Manuscript accessibility in different formats ( Pdf, E-pub, Full Text, Audio)

- Unceasing customer service

Track the below URL for one-step submission https://juniperpublishers.com/online-submission.php 